\title{
大正大礼における下賜建物の教育施設への転用過程 THE PROCESS OF CONVERTING BUILDINGS USED AT THE TAISHO ENTHRONEMENT CEREMONY TO EDUCATIONAL FACILITIES
}

\author{
原戸 喜代里*，大 場＼cjkstart修** \\ Kiyori HARATO and Osamu OBA
}

\begin{abstract}
After the Taisho enthronement, the buildings used for the ceremony were granted to various places in Kyoto. This paper shows the analysis of how these buildings in educational facilities were converted.

The time of Taisho enthronement was also the time of expanding and arranging an administration of school education. After the enthronement, dismantled buildings were granted to various educatioal institution such as elementary schools, junior high schools and high schools. When looking at the conversion of granted buildings we can see there was a different attitude of each institution toward the buildings. Their differences may have been caused by the each institution's reaction to Taisho enthronement.
\end{abstract}

Keywords : The Taisho enthronement ceremony, Granted buildings, Kyoto Imperial Palace, , Conversion, 大正大礼，下賜建物，京都御所，転用

1. はじめに

大正 4（1916）年の大正天皇の “御大礼” に際し、京都御苑や二 條離宮には多数の建物が造営された。これらの建物は、大礼終了後 に取解かれ、その多くが、京都府下の各所へ譲与され、移築された。

大正大礼の建物の下賜について調査したところ、その下賜先は宗 教施設と教育施設に大別される。前稿注1) では、宗教施設へ下賜され た建物の転用過程について論述したが、本稿では、教育施設への転 用過程の実態の解明を試みたい。

\section{2. 教育施設における転用の過程}

大正大礼終了後、儀式を執り行うために造営された仮設の建物の うち $76 \%$ は、宮内省より「建設地主管又八所在ノ官衙學校地方自治 團體二無償譲與セラレ地方自治團體二賜ハリタルモノ八各團體二於 テ直接公共ノ用ニ供シタルモノノ外地方文教ノ進歩發達二資スル為 更二學校神社寺院等二分配」注2) された。宮内省より直接建物を下賜 された「建設地主管又八所在ノ官衙學校」とは、京都市、京都帝国 大学、第三高等学校、京都高等工芸学校、京都高等虫業学校で、そ
の他は「地方自治團體」即ち京都府に一旦下賜され、京都府から府 下の 64 件へ分配された。こうして、大正大礼後に建物が下賜され た団体は、合計して 69 件にのぼる注3)

下賜先の 69 件のうち、宗教施設へ転用されたものが 16 件、教育 施設注4) 一と転用されたものは 31 件、郡町村 11 件、医療保護施設 6 件、その他団体 5 件となっており、大正大礼後、建物が下賜された 団体のおよそ $45 \%$ が、教育施設として転用したこととなる。

表 1 は下賜先 69 団体のうち宗教施設を除いたものの一覧で、網掛 け部分が教育施設へ下賜されたものである。

教育施設一の下賜 31 件の内訳は、学校教育施設 27 件、通俗教育 施設 4 件（博物館・陳列館 1 件、集会施設 3 件）となっており、学 校へ下賜されたものが多い。さらに、学校へ下賜されたものの内訳 を詳細に見ていくと、尋常小学校及び尋常高等小学校 10 件、中学校 2 件、高等女学校 7 件、高等学校 1 件、師範学校 1 件、専門及び大 学 5 件、特殊学校 1 件となり、尋常小学校と高等女学校へ下賜され たものが目立つ。

宮内省から直接下賜されたものは、京都市及び市内の官営の学校

\footnotetext{
京都府立大学大学院生命環境科学研究科

博士後期課程 $\cdot$ 修士

** 京都府立大学大学院 教授.工博
}

Graduate Student, Graduate School of Kyoto Prefectural Univ., M. Eng.

Prof., Kyoto Prefectural Univ., Dr. Eng. 
表 1 大正大礼造営物下賜先のうち、宗教施設以外に下賜されたものの一覧

\begin{tabular}{|c|c|c|c|c|c|c|c|c|c|}
\hline 下賜先団体 & 使用儀式 & 造営場所 & 下賜建物名称 & 坪数 & 転用用 途 & 現存の有無 & 図面 & 仕樣書| & 古写真 \\
\hline 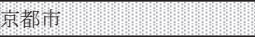 & 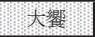 & 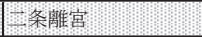 & 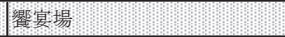 & I98: & 翏全诖 & $x$ & $x$ & XI & PII \\
\hline 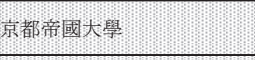 & 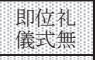 & 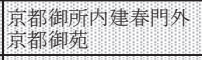 & 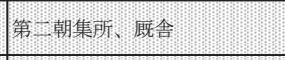 & 945 & 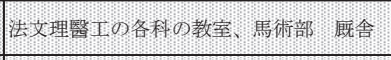 & $\times$ & XI & XI & XI \\
\hline 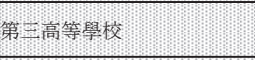 & 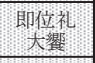 & 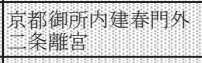 & 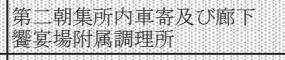 & $8: 8$ & 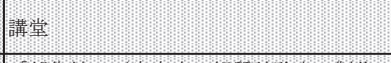 & $x$ & XII & xin & PIn \\
\hline 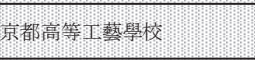 & 丹觜 & Nenter & 7) & 325 & 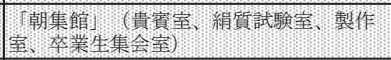 & $x$ & XI & $x$ & @1 \\
\hline 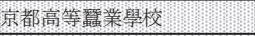 & X籍 & 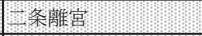 & 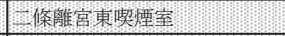 & 63 & 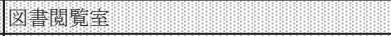 & X & $x$ & X & 0) \\
\hline 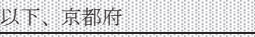 & & & & $\frac{\pi}{2}$ & & II & ? & L & บ11 \\
\hline 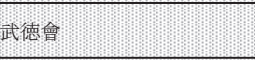 & X融 & 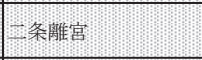 & 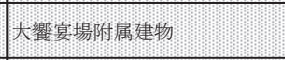 & 14 & 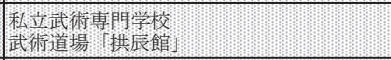 & 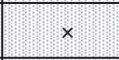 & (1) & $x$ & X) \\
\hline 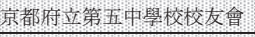 & -1 & 我翡 & 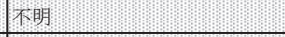 & 110 & 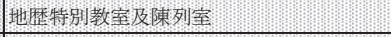 & $x$ & X! & $x$ & XI \\
\hline yil & Eil1: & 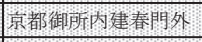 & 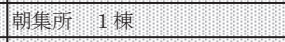 & 9 & 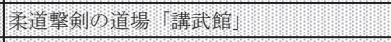 & $x$ & 0 & 9 & (1) \\
\hline 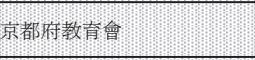 & 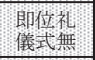 & 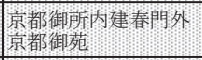 & 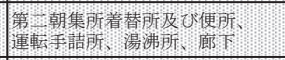 & 183 & (y) & $\times$ & (1) & XI & @ \\
\hline 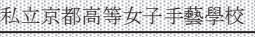 & - & 我䦕 & 我盟 & 3 & 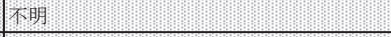 & $x$ & $x$ & a & $x$ \\
\hline 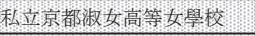 & -1 & 原開 & [irinan & 3. & 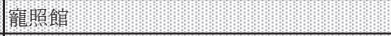 & $\times$ & $x$ & $x$ & O \\
\hline 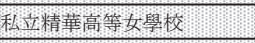 & 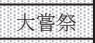 & Nes & 障会 & 78 & 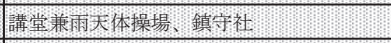 & $x$ & $x$ & $x$ & d) \\
\hline 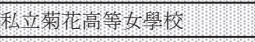 & I.:- & 1这推所 & 䜷㑒 & 78. & 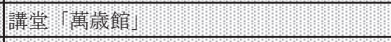 & $\times$ & XI: & 政 & XI \\
\hline 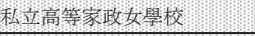 & -1 & 1 & 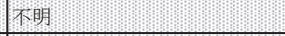 & 41 & 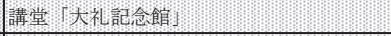 & $\times$ & $x$ & $x$ & Oा \\
\hline 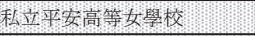 & 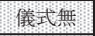 & 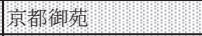 & 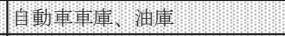 & 41 & 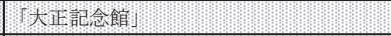 & $\times$ & $x$ & $\times$ & 0 \\
\hline 16) & - & - & $-1-1$ & 29 & 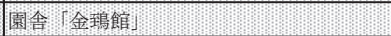 & $x$ & $x$ & $x$ & 0 \\
\hline Why & enen & 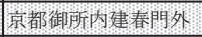 & 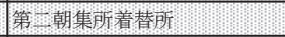 & 109 & 父青鎮 & XI & $x$ & $x$ & XI \\
\hline 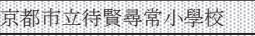 & X籍 & ren & 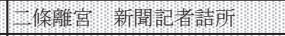 & -1) & 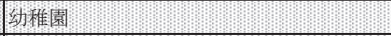 & XI & $x$ & X & $x$ \\
\hline 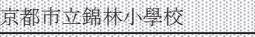 & 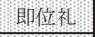 & 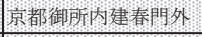 & 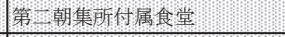 & 63: & 㒹空 & X & XII & $x$ & $x$ \\
\hline 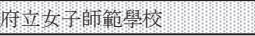 & -1 & - & - & 104 & - & - & -12 & -1 & - \\
\hline 愛宕郡雲ケ烟村 & 大㗽 & 二条離宫 & 嘅宴場付属椅子卓置場及廊下 & 73 & 役場及び御椫場休頺所 & $\times$ & $\times$ & $x$ & $x$ \\
\hline 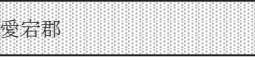 & ]㽝: & 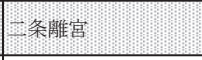 & {$\left[\begin{array}{ll}\mid \\
{[1}\end{array}\right.$} & 97 & 사르. & $x$ & $x$ & X] & X \\
\hline 愛宕郡上賀茂村 & 儀式無 & 京都御苑 & 厩舎 & 73 & - & - & - & - & - \\
\hline 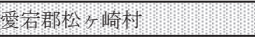 & 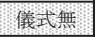 & 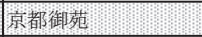 & 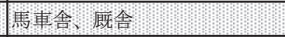 & 63. & 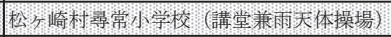 & $\times$ & 0 & (1) & $\times$ \\
\hline 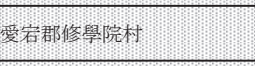 & 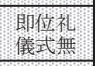 & 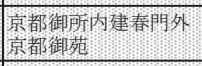 & 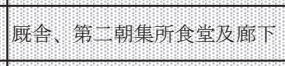 & 86 & 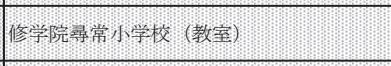 & XI & 0 & 0 & $x$ \\
\hline 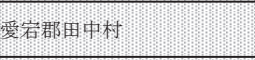 & 義武無: & (5) & 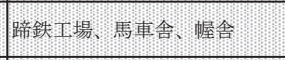 & 79 & 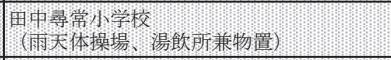 & $x$ & $x$ & $x$ & $x$ \\
\hline 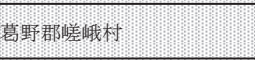 & 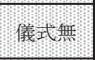 & 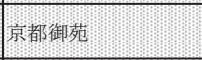 & 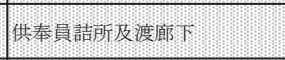 & 22 & $($ (1) & X & 0 & XI & $x$ \\
\hline 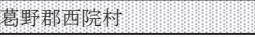 & 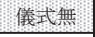 & 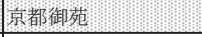 & 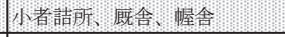 & 84 & 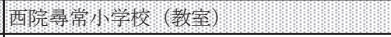 & $x$ & X!n & X & $X$ \\
\hline 葛野郡小野鄉村 & \begin{tabular}{|l|l} 
儀式無 \\
\end{tabular} & 京都御苑 & 新聞記者控所、厩舎 & 71 & - & $\times$ & - & - & - \\
\hline HOn & 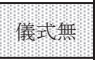 & 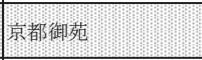 & 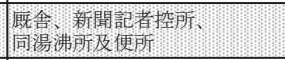 & 94 & 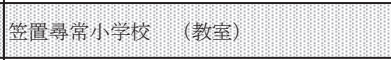 & $x$ & ก: & X! & X \\
\hline 綴喜郡田原村 & \begin{tabular}{|l|} 
即位礼 \\
儀式無 \\
\end{tabular} & 大宮御所、京都御苑 & 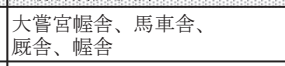 & - & - & - & - & - & - \\
\hline 船井郡 & 大㗽 & 二条離宫 & 二条離宫衛兵舎、食堂 & 88 & - & - & - & - & - \\
\hline 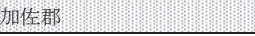 & 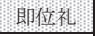 & 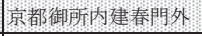 & 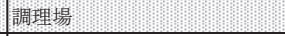 & - & 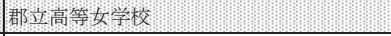 & $x$ & X) & X! & X \\
\hline 南桑田郡 & 大嘗祭 & 大宮御所 & 采女詰所 & 60 & - & - & - & - & - \\
\hline 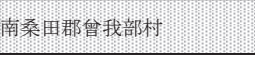 & - & |xe? & 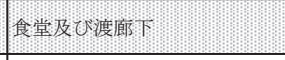 & 57 & 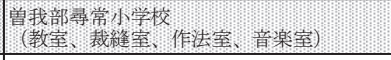 & XI & 0 & xin & $x$ \\
\hline 南桑田郡篠村 & \begin{tabular}{|l|} 
大档祭 \\
傜式 \\
\end{tabular} & 大宮御所、京都御苑 & 幄舎、小者詰所 & 54 & - & - & - & - & - \\
\hline 何鹿郡東八田村 & \begin{tabular}{|l|} 
儀式無 \\
\end{tabular} & 京都御苑 & 馬車舎、幄舎 & 26 & - & - & - & - & - \\
\hline 何鹿郡以久田村 & \begin{tabular}{|l|l} 
儀式無 \\
\end{tabular} & 京都御苑 & 馬車舎、幄舎 & 40 & - & - & - & - & - \\
\hline 何鹿郡綾部町 & 儀式無 & 京都御苑 & 馬車舎、厩舎、幄舎 & 99 & \begin{tabular}{|l} 
綾部町立尋常高等小学校 \\
(教空、郞下、物置)
\end{tabular} & $\times$ & 0 & 0 & $x$ \\
\hline 紀伊郡堀内村 & \begin{tabular}{|l|} 
儀式無 \\
\end{tabular} & 京都御苑 & 馬車舎、幄舎 & 54 & - & - & - & - & - \\
\hline 紀伊郡東九条村 & \begin{tabular}{|l|l} 
儀式無 \\
\end{tabular} & 京都御苑 & 小者詰所 & 41 & - & - & - & - & - \\
\hline 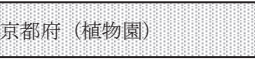 & ementen & 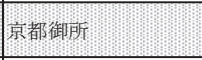 & 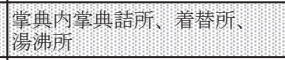 & 301 & 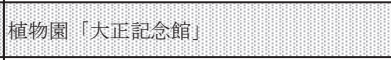 & X & X? & X! & XI \\
\hline 京都棋橘財團 & - & - & 御大礼御使用建物 & \begin{tabular}{|r|}
105 \\
\end{tabular} & 事務所（会議室、事務室） & $\times$ & $\times$ & $\times$ & $x$ \\
\hline 赤十字社京都支部 & - & - & - & 274 & - & - & - & - & - \\
\hline 済世病院 & \begin{tabular}{|l|} 
儀式無 \\
\end{tabular} & 京都御苑 & 小者調理場 & 63. & 病室掂張（東寺内に建設） & $x$ & $x$ & $x$ & $x$ \\
\hline 篤志看護婦人會葛野分會 & - & - & - & 71 & - & - & - & - & - \\
\hline 愛國婦人會京都支部 & - & - & 御大礼御使用建物 & 82 & 事務所（二階建） & $\times$ & $\times$ & $\times$ & $\times$ \\
\hline 平安垍育院 & \begin{tabular}{|l|l} 
儀式無 \\
\end{tabular} & 京都御苑 & 自動車車庫 & 41 & 院舎 & $\times$ & $\times$ & $\times$ & $\times$ \\
\hline 平安徳義會＼cjkstart孤児院 & 儀式無 & 京都御苑 & \begin{tabular}{|l} 
運転手詰所、浴室及便所、 \\
\end{tabular} & 55 & 院舎 & $x$ & $\times$ & $x$ & $x$ \\
\hline 京都商業會議所 & \begin{tabular}{|c|} 
大嘗祭 \\
\end{tabular} & 大宮御所 & 幄舎 & 90 & 京都名產品陳列館 & $\times$ & $\times$ & $\times$ & $\times$ \\
\hline 愛宕郡白川村在郷軍人會 & - & - & - & 30 & - & - & - & - & - \\
\hline 愛宕郡八瀬村青年會 & - & - & - & 27 & - & - & - & - & - \\
\hline 久世郡佐山村青年會 & - & - & - & 30 & - & - & - & - & - \\
\hline
\end{tabular}

凡例 儀式無 : 儀式に直接使用しない建物

(『大正大禮京都府記事』『大礼記録』『大礼関倸録』沿革史等により作成)

一：下賜の事実関係が不明、又は下賜先の団体の所在が不明なものを示す 
(京都帝国大学、第三高等学校、京都高等工芸学校、京都高等虫業学 校）で、それらには、饗宴場や朝集所など大饗に関わる建物 1 棟分 の取解材がそっくり下賜され、下賜坪数も京都高等虫業学校以外は 数百坪という大きなものとなっている。

一方、宮内省から一旦京都府へ下賜し、京都府が各下賜先一分配 したものについて表 1 を見ると、尋常小学校や高等女学校など一ヶ 所の下賜先に対して、馬車舎や厩舎など事務方の建物の取解材が複 数種とり混ぜて下賜され、下賜坪数についても 100 坪以下の比較的 小さいものが多い。下賜坪数が 100 坪を超えるものも見られるが、 これらには第二朝集所や饗宴場に付属する建物が下賜されており、 京都府が分配したものについても、下賜坪数が多いものについては、 宮内省から直接下賜されたものに準じた下賜が行われている。

大正 4 年 2 月、江木内閣書記官長が京都帝国大学総長を始めとす る各下賜先代表に宛てた書簡では「過日協議ニ及ヒタル大禮建物保 管轉換ノ件二付其用途目的物ノ範囲其他詳細ノコト

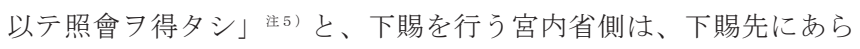
かじめ転用建物の詳細を報告させていたことがわかる。宮内省が直 接行った高等教育機関への下賜については、転用建物の用途が考慮 された上で、饗宴場や朝集所など大饗に関わる建物が選ばれ、それ らの建物 1 棟分の取解材が下賜された。

京都府が下賜先を查定し分配したもののうち、下賜坪数の小さい ものについては、儀式とは直接関わらない厩舎や車庫、詰所等の取 解材を複数種混在させて下賜されたことから、下賜する側は、転用 用途を考慮し、下賜材が建築材料として使用されることを予め意識 して下賜建物を選択していたのではないかと考えられる。

さらに、これら各教育施設における下賜建物の転用用途を同表よ り確認する。尋常小学校では、教室に転用されている事例が多く、 その他の学校では、講堂へ転用されたものが多い。通俗教育施設で は、公会堂や植物園内施設に転用されている。

以上、表 1 より教育施設における下賜過程を検討してきたが、尋 常小学校では、儀式に直接関わりのない複数の下賜建物の取解材が 一つの学校に下賜され、それらは主に教室に転用されていた。尋常 小学校での転用の過程からは、大礼の建物という特別な建物を取り 扱う意識は見いだせず、下賜建物の取解材は、むしろ建築材料とし て受取られ、通常の建物の移転、転用の過程に類似していると想像 できる。

また、高等女学校では、幄舎の一部や車庫、調理所等が下賜され るが、これらは講堂として転用されている。下賜建物の取解材は、 尋常小学校と同様に建築材料として受取られ、元の建物とは異なる 全く新たな建物を作り出していると思われる。しかしながら、転用 された建物には大礼に関わる名前をつけ（表 1 中「転用用途及び施 設名」欄参照)、建物の記念性を主張している点は、尋常小学校の転 用過程と異なっている。

大学や専門学校などその他の学校は、朝集所や二條離宮の饗宴場 の附属建物が講堂等集会のための施設に転用されている。通俗教育 施設についても同様である。朝集所や饗宴場の附属建物等、集会の ための施設が、講堂や公会堂など集会施設へ転用されていることか ら、大礼当初の建物の形式を踏襲しつつ転用されたことも考え得る。

教育施設に転用された建物で現存寸るものは見つからなかったが、 次章では、実際の転用過程を資料から確認していきたい。

\section{3. 下賜建物の転用事例}

\section{3-1. 尋常小学校}

尋常小学校では、明治 33 年の小学校令改正により、年限四力年制 と授業料が廃止されたため、就学率が、著しく向上する。さらに、 同 41 年には義務教育が 6 个年となり、尋常小学校における児童数が 増加した。大正初期は、小学校教育が普及し、拡充された時期であ るといえる。

\section{·愛宕郡修学院村立尋常小学校}

愛宕郡修学院村には、第二朝集所食堂 54 坪、同食堂廊下 2 坪、厩 舎の内 30 坪の合計 86 坪が下賜された。修学院村では、これらの下 賜材を村立尋常小学校の教室に充当することを議会で決議、大正 5 年 10 月 11 日付で、愛宕郡長熟野米太郎が、京都府知事木内重四郎 宛に、小学校校舎増築の申請の文書を提出している。

これに依ると「本年八教室及其他ヨ新築シテ漸ク現在ノ児童 収 容シ居候へ共明年度八学齢览童増加ノ見込ニテ教室増築ノ必要有之

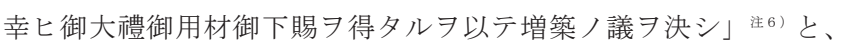
大礼建物の取解材の下賜を契機に、坚童増加に依る教室不足を解消 すべく教室の増築を決定したとある。

この増築工事の見積書によると、柱や陸梁、合掌、垂木、野地板、 軒先裏板などの屋根廻りの部材、土台、大引、根太、床板等の床迴 り、内外腰張りや胴縁等壁廻り、敷居鴨居、空硝子戸、入口戸等の 建具廻り、箱金物、合掌用ボールト、丹尺金物、釘カクシ等金物類、 柱石及び束石等の備考欄に「但し古材料使用二付無料」と大礼の下 賜材が使用されていることがわかる。この見積書から、新教室の増 築には、主に大礼の下賜材が使用され、その不足部分を新材で補っ ている様子が見て取れる。

京都府知事に宛てた行政文書からは、大正大礼の建物の下賜を記 念するというような文言は見いだせず、大礼の下賜材は、教室建築 のための材料として活用されていた。

\section{·愛宕郡田中村立尋常小学校}

田中村立尋常小学校には、京都御苑内の蹄鉄工場、馬車舎及び幄 舎の一部の合計 79 坪が下賜されている。

使用用途を屋内体操場としている愛宕郡田中村では、大正 5 年 9 月 14 日付、愛宕郡長から京都府知事宛の校舎増築許可申請書に、「本 郡田中尋常小学校八昨年教室増築ノ際従来ノ屋内体操場 7 取毁チシ ヨリ児童教養上不便不尠ノ為二本年度二於テ之ガ建設ヨ計畫セル際 御大禮建物ノ下賜 屋内体操場をつぶして教室を確保したため、下賜された建物は雨天 体操場及び湯吞所兼物置所に充当された。

\section{- 何鹿郡綾部町立尋常高等小学校}

綾部町立尋常高等小学校には、馬車舎、厩舎及び幄舎の一部合計 99 坪が下賜され、教室、物置、廊下に転用された。

大正 6 年 3 月の綾部町長から京都府知事宛の文書によれば「小學 児童八累年増加ノ傾向 示シ學級数増加ノ必要习生シ現在ノ校舎二 テハ到底収容スルヨ能ハズ教育上支障不尠ヨ以テ教室増築計畫中, 処今回忝クモ御大禮用建物ノ一部下賜相成タルヨ以テ之レカ材料ニ

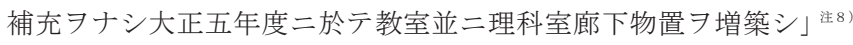
とある。綾部町立尋常高等小学校に於いても、当時の急激な児童増 増加による教室不足を解消寸るために、大正大礼の建物の下賜材が 活用された。 


\section{3-2. 高等女学校}

初等教育の普及がなされると中等教育整備への要求が高まってく る。従来中学校令に組み込まれていた高等女学校についても、明治 32 年には高等女学校令として新たに規定された。「明治 $37 、 8$ 年戦 役以降の女子教育の発展はめざましいものがあり、高等女学校の学 校数の増加および生徒数の増加の上にもこれがあらわれている。実 科高等女学校は、高等女学校令が改正された翌年の明治 44 年には 49 校が新設され、生徒数は 4,772 人であったが、その後急速に増加 し、 5 年後の大正 5 年には、校数は 3 倍の 149 校に、生徒数におい ては 4 倍強の 21,198 人に達して」注9)いた。

表 1 の下賜先の女学校の設立時期を見てみると、私立平安高等女 学校（キリスト教系）は明治 27 年、私立京都淑女高等女学校（真宗 東本願寺派) は明治 34 年、私立京都高等女子手芸学校は明治 35 年、 私立菊花高等女学校は明治 36 年、私立高等家政女学校（浄土宗知恩 院派）は明治 37 年、精華高等女学校（神道系）は明治 38 年、と明 治末期に相次いで設置されている。この時期、京都府が設置した府 立・市立学校のみでは、府民の要求はみたされず、私立学校が数多 く設置された。その中でも仏教各派の総本山・大本山が多い京都で は、仏教各派の経営する中学校、女学校の設立が相次いだ。

大正大礼の挙行された大正初期は、高等女学校においても、学内 の整備、拡張が求められてた時期であると考えられる。

\section{・私立平安高等女学校}

私立平安高等女学校には、自動車車庫（80 坪）平安養育園と折半 40 坪、同洗場床板張 30 坪、油庫 1 棟 1.5 坪が下賜される。大典記 念事業として、生徒の作法や裁縫、料理、茶道の稽古、同空会の会 合等のための建物が建てられ「大正記念館」と命名された。

京都御苑に造営された自動車車庫及び油庫の構造形式は『大礼記 録巻百五』によると「自動車車庫及同洗場 柱堀建屋根切妻造柿莫 側及夢羽目板張柱杉材貫指、組小屋松杉材西洋合掌組杉柿板亘とあ り、油庫については、柱杉材掘建屋根招造亜鉛引浪形鐵板莫 側外 部松羽目板内部亜鉛引鐵板張床力」梁10)となっている。

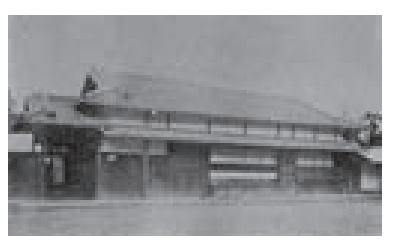

写真 1

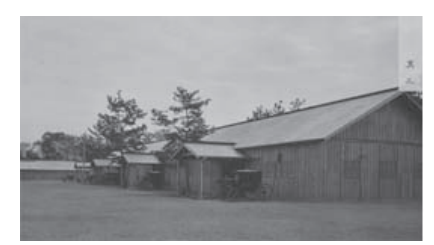

写真 2 自動車車庫注 ${ }^{2}$
大正記念館の形式は、写真 1 を見ると、屋根は入母屋造り瓦草き、 外壁は漆喰、腰板が張られている。『大礼記録』に記されている構造 形式や大礼当時の写真と比較してみると、大正記念館は大礼当初の 建物の形式を踏襲したものではなく、大礼の下賜材を活用し、生徒 の稽古室や集会のための施設として建築されたものと考えるのが妥 当であろう。しかしながら、転用された建物には「大正記念館」と いう名前がつけられ、大礼を記念しょうとした様子が窥える。

\section{・私立家政高等女学校}

明治 37 年に因幡薬師内 (下京区鳥丸松原下ル) 仮校舎に設立され
た家政高等女学校は、大正初めに在校生が 200 余名となり校舎が狭 险となる。大正 5 （1916）年、校舎を大雲院山内（下京区寺町四条 下ル）に移転、校舎も新築した。

沿革史では、「5 月 25 日には、大正天皇御即位大典時の建物の一 部を拝領、これを移築して「御大禮記念館」とし、費用は卒業生の 寄付のみによってまかなわれた。しかし、何分にも資金が充分でな いため、仮校舎の資材のうち使用できるものはことごとく移して利 用寸る計画であったので、工事の進み方と共に使用中の校舎が次々 と壞されていく状況で、その間の不自由や混乱は察するに余りある ものであった。」洋13) と当時、経済的に困窮していた様子が窺え、そ のような状況下における下賜は、建築材料を無償で得られる好機で あったといえる。しかしながら、建築した建物に「御大禮記念館」 と命名し、大礼の記念性を保持しょうとした点は尋常小学校と異な っている。

\section{・私立精華高等女学校}

私立精華高等女学校は、明治 38（1905）年皇典講究所により設立 された神道系の女学校である。

同校の沿革史によると、大正 5 年 6 月に大礼建物（詳細は不明） の一部が下賜され、大礼記念建造物として記念講堂兼雨天体操場と 本館（校長・事務・作法室）が建設された。さらに、大正 8 年 4 月 大嘗祭に使用された幄舎が下賜される。この下賜を記念して鎮守社 が建設され、学園一同の精神的支柱として厚く尊崇された。

精華高等女学校は、神道系の学校であったため、記念建造物の他 にも大礼記念事業として鴨川堤に柳樹を植えたり、校庭の隅に伊勢 神宮遥拝所を設ける等、盛大に大礼を記念しょうとした。

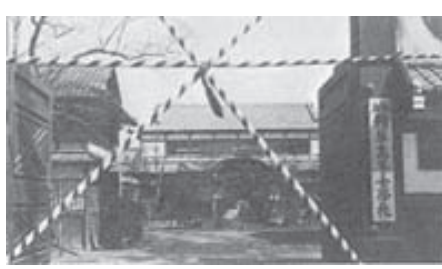

写真 3 本館 (i土 $^{14}$

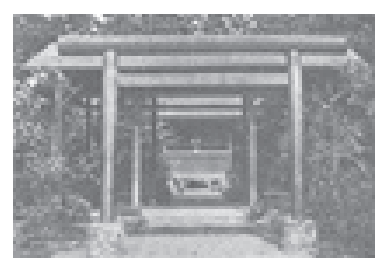

写真 4 鎮守社注 15

\section{3-3. 大学及び専門学校、その他}

\section{- 第三高等学校}

第三高等学校では、大正 5 年 3 月に「母校の懇願に對し御大典用 臨時造営物中、第二朝集所御車寄及ひ二條離宮内饗宴場附属調理所 下賜の御沙汰に接し、直に之を校内に移轉し、且つ右朝集所は、略 ほ原形のまま併せて之を移築することとなりしのみならず尚右調理 所は母校より建築材料として全部之を交附せらるることと関係者の なりしたれば両者相俟つて、益々大典記念の趣旨を深くするに至れ

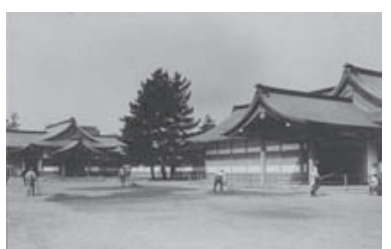

写真 5 第二朝集所注 16$)$ （京都府立総合資料館所蔵）

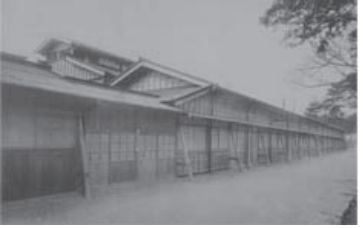

写真 6 二條離宮内 饗宴場附属調理所 ${ }^{(i z}$ 17) 


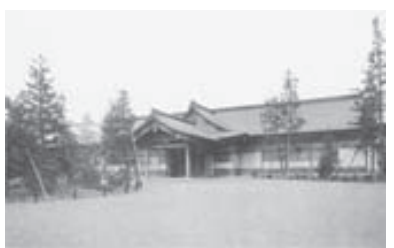

写真 7 尚賢館注 18

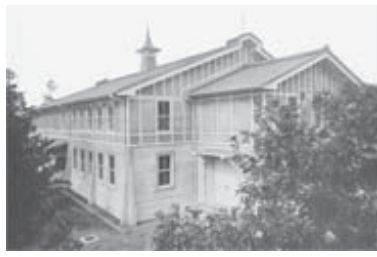

写真 9 新徳館注 201

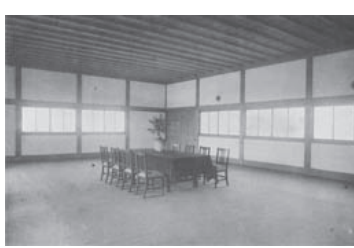

写真 8 尚賢館内部注 19

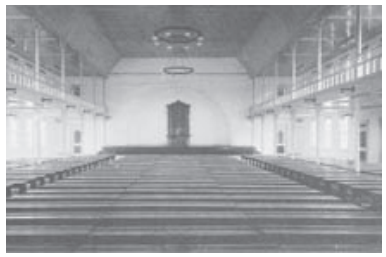

写真 10 新徳館内部渓 21

(写真 7、8、9、10 京都大学文書館所蔵)

る」注 22) と、第二朝集所の一部を移築し、「略ほ原形のまま」建てら れた「尚賢館」と、饗宴場附属調理所の取解材を建築材料として使 用した武田五一による講堂「新徳館」が建てられた。

\section{·同志社大学}

同志社大学には、第二朝集所の内の 93 坪が下賜され、道場として 転用されている。大正 5 年度の同志社社長報告のなかで「大正 4 年 の御大典に際し御所内に設置せられたる朝集所の内 1 棟を本社に下 賜せられたるを以て新たに材料を加へ地を運動場の西北部にトし大 学及中学々生の為めに柔道撃剣の道場を建築することとせしが大正 5 年 11 月を以て竣工したるに付講武館と命名寸 (中略) 斯くて多年 其欠乏を感じたる道場を得たるの夕ならず併せて曠古の盛典を記念 するを得るは吾等の喜悦に堪へざる所なり」注 ${ }^{23)}$ と当時の様子が語 られている。

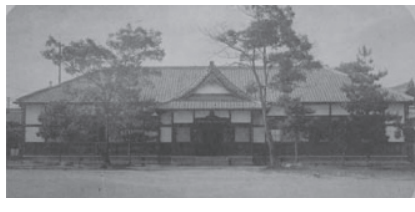

写真 11 講武館注 25)

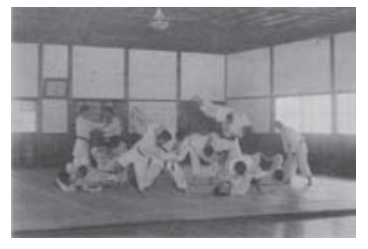

写真 12 講武館内部洋 26)

(写真 11、12 同志社大学社史センター所蔵)

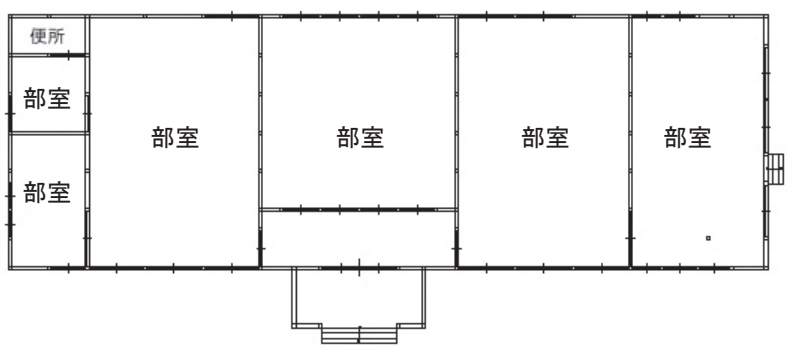

図 1 講武館平面図（昭和 30 年移築）

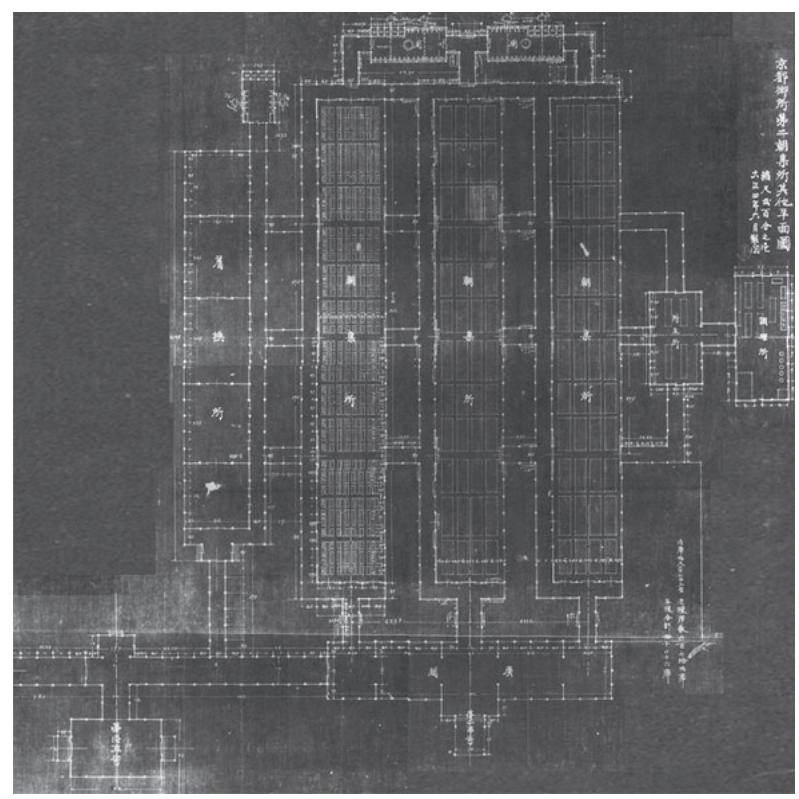

図 2 第二朝集所平面図 ${ }^{\text {27) }}$ (宮内庁書陵部所蔵)

この道場の様子を、京都日出新聞では、「同志社大学にては昨秋大 典朝集所建物一部を下賜せられたるを以て大典記念館として構内に 移築せる (中略) 記念館の広さは 130 坪洋館立ち並ぶ間に御所造り の原型の面影を存し柔道及び剣術の道場に宛つるべく竣工の上は大 學及普通學校の柔道部剣道部員は放課後大に奮闘練習することにな れり(下線筆者)」注24) と伝えている。

図 1 は講武館が昭和 30 年に移築された時の平面図である。この図 では内部が間仕切られ、部室として使用されているが、講武館の写 真 12 を見ると、柔道場として使用されており、建築当初には、内部 の間仕切りはなかったと見られる。

しかし建物の規模は当初のままであり、図 2 の第二朝集所の平面 図と比較すると、講武館の柱間はほとんど元のままで建てられてい ることがわかる。また、その規模から、3 棟ある朝集所のうちの約 0.5 棟を下賜されたと考えられる。

大礼当初の写真 11 と朝集所の写真 5 とを比較してみると、玄関の 屋根は入母屋とし瓦棟に獅子口、妻飾りは懸魚、柱間は白漆喰塗り で長押が回されガラス公が嵌められるなど、当時のものをそのまま 建てたとはいえないが、「御所造りの原型」を感じさせる意匠として いる。

同志社大学では、大礼の下賜材で建築した道場を、大礼当時「御 所造りの原型の面影」に似せた形で建築し、大礼の記念性を保持し ようとする指向が窥えた。

\section{・京都府教育会}

京都府教育会には「第二朝集所ノ内 87.47 坪、同附属便所ノ内 10 坪、自動車車庫内運転手詰所、同湯沸所、同廊下、第二朝集所衣換 所、同廊下八内 8.96 坪、廊下ノ一個所 3.735 坪」注 28$)$ 以上、合計約 184 坪が下賜されている。

当時の京都府教育会は、京都府構内にあり「借家にして事務執行 上の不便㪇からざりしと雖も本會の本領たる事業の施設規畫の更に 急務成ものあり為に會館建設の資を蓄ふる餘財を有するに至らず、 
巳むを得ず不便を忍びつつ以て今日に及べり」洋299)という状況であっ たところ、「大禮建築物下賜の恩命に浴したりき大禮記念建築物とし て最も適応したるものなるが故に理事者に於いては此の機を逸せず 年来の素望たりし会館建設の議を決するに至れり」洋30) と大礼の建物 の下賜が、教育会館建設と事務所移転の後押しをすることとなる。

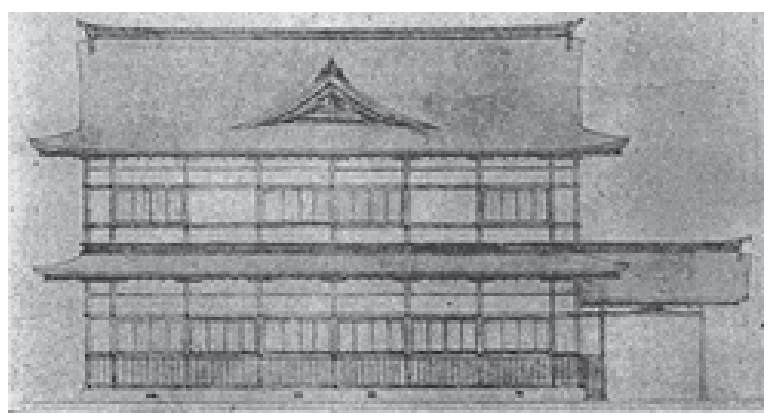

図 3 教育会館側面図注 31 )

教育会館は、賀茂川沿いに建設されるが「背景として東山連峰を 負ふ景勝の境を得たるを以てこの純京都式の風物景象との調和を失 せざる建築に多大の考慮を要す。(中略) 其の設計を内匠頭馬場三郎 氏に依頼し内匠頭は更にこれを宮内省技師中村誠氏に命ぜられて日 本固有の破風造りによる建築法による設計」注 32 で、木造二階建て総 建坪 120 坪の会館に、車置 4 坪、地方会員のための無料宿泊所 20 坪、その他附属建物 24 坪を加えた合計 160 坪の建物が建てられた。 京都府教育会は、朝集所等数種の下賜建物の取解材を用いて建築 された新たな教育会館の設計を、京都府の技師ではなく、宮内省内 匠頭に依頼した。これにより、まさに「大禮記念建築物として最も 適応したるもの」を建てようとしたのであろう。

\section{4. むすび}

以上、大正大礼の際に下賜された建物が、教育施設一転用される 過程を検討した。

大正大礼の挙行された時期は、学校教育制度が整備され、初等教 育が普及し、それに伴い中等教育への要求が高まった。大礼建物は、 下賜された建物の多くは学校施設、特に尋常小学校と高等女学校の 施設へと転用された。

昭和大礼の下賜建物の転用事例で比較的多く見られた社会教育の ための諸施設は注33)、漸く通俗教育に目を向けられ始めたこの大正期 にあってはまだ少ない。

下賜する側については、下賜建物が転用後どのように使用される のかを予め意識し、転用後の用途や規模に応じた建物を下賜したと 考えられる。

学校の施設として転用された実態をそれぞれ探っていくと、尋常 小学校では、下賜建物を建築部材として取扱い、大礼建物の下賜を 記念しょうとする様子は見いだせなかった。高等女学校においては、 下賜された建物は建築部材として活用されたものの、新たに建てら れた建物に大礼を記念する名前をつけることで、大礼建物の下賜を 記念しょうとしていた。

これは尋常小学校や高等女学校に下賜された建物の取解材を、下 賜する側は、通常の建築材料として使用可能なものと認識し、拝受

した尋常小学校でも通常の建築材料として認識していたといえる。 しかしながら同じ拝受者である高等女学校では、建築材料であって もそれが大礼を記念するものであると認識していた。

宮内省から直接下賜された官営学校では「略ほ原形のまま併せて 之を移築」し大礼を記念しょうとする様子も窥えた。

このように、大正大礼の下賜建物を拝受した学校における転用の 状況には、大礼建物下賜の記念性に対する隔たりがみられた。

大正大礼の下賜では、大礼の下賜建物に特別な意味を付与するか どうかの認識が、初等教育機関、中等教育機関、高等教育機関で異 なっていたといえる。

大正大礼の 13 年後に挙行された昭和大礼では、各教育機関は一様 に大礼の下賜建物に対し特別な意味を付与し、たとえ柱 1 本にでも 特別な意味を見い出し記念保存のために下賜を願い出るというょう な小学校の事例洋 34 も見られた。このように、大礼の下賜建物に対 する認識が 13 年という短期間に大きく変わったのは、御真影の下賜 の普及洼 ${ }^{35}$ や国民に対し天皇尊崇の観念の浸透を目的とした社会教 育の徹底が、大正大礼の後から展開されてくること注 ${ }^{36)}$ と関わって くるのではないかと考えられる。

下賜建物に対するこのような認識の格差が、下賜建物の転用実態 の相違を生んだといえよう。

\section{参考文献}

1）京都市:京都の歴史 8 古都の近代, 學藝書林, 1975.3.20

2）山本信良・今野敏彦: 大正・昭和教育の天皇制イデオロギー [ I ], 新泉 社, 1976.3.1

3）京都府教育會: 京都教育 第 239 号-第 307 号, 1912.5.10-1918.1.10

4）京都市教育會: 京都教育時報 第42 号-第 115 号, 1911.11.15-1915.12.27

5）歷史的建造物保存調查専門委員会: 京都大学建築八十年のあゆみ・京都大 学歴史的建造物調査報告書, 1977.6.1

6) 財)千里文化財団:京都の仏教史, 平河出版社、1992.2.1

注

注 1）拙稿「大正大礼における下賜建物の宗教施設への転用過程」日本建築 学会計画系論文集 第 75 巻 第 658 号, 2010.12

注 2）『大禮記録 第 106 巻 建物処分並残務処理』国立公文書館所蔵

注 3）前掲 1）参照

注 4）ここでいう教育施設とは、大正大礼の挙行された大正初期に、文部省 が管轄した教育施設、学校教育施設及び通俗教育施設をさす。

注 5）『公文類聚第井九編 大正四年 巻一ノ五』国立公文書館所蔵

注 6) 京都府庁文書『大正 5 年 設備 学務課』京都府立総合資料館所蔵

注 7） 前掲 6)

注 8）京都府庁文書『大正 6 年 設備 学務課』京都府立総合資料館所蔵

注 9）文部省『学制八十年史』p. 186, 1954

注 10）『大禮記録 第 105 巻』国立公文書館所蔵

注 11)『平安女学院 100 年のあゆみ』1959.3

注 12)『大正大礼の記録写真』国立公文書館所蔵

注 13)『京都文教学園の百年』p. 47, 2004.11.3

注 14) 精華百年史編纂委員会『精華百年史』2005.11.9

注 15) 前掲書 14)

注 16）『大礼関係写真』京都府立総合資料館所蔵

注 17）『二條離宮大饗宴場建築写真帖』奥付なし

注 18）『第三高等学校創立満 50 年大典記念館落成記』 1918.5

注 19）前掲書 18)

注 20）前掲書 18）

注 21）前掲書 18）

注 22）前掲書 18），p. 103，

注 23）学校法人同志社『同志社百年史 資料編 1 』p. 905, 1979.11.29

注 24）『京都日出新聞 大正 5 年 11 月 11 日 夕刊』同志社大学所蔵

注 25）『大正大礼関係写真』同志社大学社史センター所蔵 
注 26)『同志社大学卒業アルバム』同志社大学社史センター所蔵 注 27) 大礼関係録 大正, 宮内庁書陵部所藏

注 28) 京都府教育会『京都府教育会 50 年史』p. 50, 1930.11.3

注 29) 京都府教育会会報『京都教育 292 号』p. 25, 1916.10.10

注 30) 前掲書 29) , p. 25

注 31) 前掲書 28)，pp. 50-51

注 32) 前掲書 29) , p. 26

注 33)教育学者の下村壽一は昭和初期に編集された『教育科學』中の「教育 行政」において社会教育施設を「一般民衆の為の修養手段としての施 設」であるとし「一、書館、巡回文庫、通信教授以圖。二、博物館、 動物園、植物園、其他の観覽施設。三、講演會、講習會、成人講座。 四、活動映畫、ラ夭゙オ。五、各種教化團體。六、男女青年團、少年少 女團、隣保館。」が社会教育施設の主なものであるとしている。(岩 波茂雄『岩波講座 教育科學 $\mathrm{V}$ 教育の制度』p. 77, 岩波書店, 1931）昭 和大礼では、社会教育の推進に伴い、成人教育の講演会、公民教育講 座等が学校で開催されたため、下賜建物は、講堂や図書館、転用され る事例が目立った。（拙稿「昭和大礼における下賜建物の教育施設一 転用過程」日本建築学会計画系論文集第 650 号, pp. 915-920, 2010.4
参照)

注 34）拙稿「昭和大礼における下賜建物の教育施設への転用過程」日本建築 学会計画系論文集 第 75 卷 第 658 号, pp. 915-920, 2010.4 参照

注 35）御真影の下賜について籠谷氏は、「御真影は明治 15 年頃から主要な 文部省直轄学校、、明治 20 年以降、主要な尋常師範学校や尋常中学校 といった府県立学校へ下賜された。高等小学校への下賜は明治 22 年末 から同 25 年末にかけて行われ、尋常小学校へ普及寸るのは、この後の ことである。尋常小学校への下賜の状況は府県によってばらつきがあ り、京都府の尋常小学校では、大正 4 年で $11.4 \%$ 、昭和 6 年になって ようやく $60 \%$ を超えるようになる。」と述べている。（籠谷次郎『近 代日本における教育と国家の思想』pp. 89-92, 阿吽社, 1994. 7. 2)

注 36）大正 10 年、通俗教育が “社会教育” と改称され、同 13 年には、文部 省普通学務局内に、社会教育課が設置される。昭和大礼の挙行された 昭和 3 年は、家庭学校以外で行われる教育的活動である社会教育が、 組織化の道程に入りつつある時期であった。

（2010年10月10日原稿受理，2011年 3 月24日採用決定） 